\title{
Do Financial Analysts Facilitate Investors' Assessment Of Earnings?: Evidence From The Korean Stock Market
}

\author{
Sukyoon Jung, Hanyang University, South Korea \\ Yong-Seok Lee, Hannam University, South Korea \\ Seong-jin Choi, Hanyang University, South Korea
}

\begin{abstract}
This paper seeks to enhance our understanding offinancial analysts in assisting market investors' use of accounting earnings in the Korean stock market. We examine whether stock returns differentially reflect earnings information for firms with analyst coverage. We propose that the role of analysts as external monitors as well as information intermediaries enhances the market investors'valuation of earnings. We find that market valuation of earnings is higher for firms with analyst following. Furthermore, market investors'valuation of earnings increases (or decreases) with the number of analysts (or with the dispersion of analysts'forecasts). This suggests that the beneficial effect of analysts arises through the quantity and quality of analysts' information. This study contributes to the literature by investigating the important role of analysts in emerging market.
\end{abstract}

Keywords: Financial Analysts; Value Relevance; Earnings Response Coefficients

\section{INTRODUCTION}

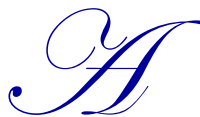

ccounting earnings are one of the most important inputs in the valuation of a firm. This is corroborated by the enormous evidence that changes of earnings are correlated with returns (see Barth et al. 2001). Further, such correlation (which is often referred as an earnings response coefficient (ERC) in the literature) varies with firm characteristics (Kothari and Collins 1989) and earnings attributes (Basu 1997; Kormendi and Lipe 1987). We argue that market investors' valuation of a firm's earnings is higher for firms with analyst following. Analysts interpret disclosed financial information and disseminate such interpreted information to market investors (Healy and Palepu 2001). This information interpretation and dissemination role of analysts helps investors better digest information in earnings and more use such interpreted earnings information in their valuation.

In addition, the monitoring role of analysts increases the quality of earnings (Yu 2008). When reported earnings have less opportunistic bias and error, they have a greater effect on investors' valuation of the firm (Francis et al. 2007; Lang et al. 2006). If analysts effectively play roles as information intermediaries and external monitors, then we expect to observe the increased relevance of earnings for firms followed by analysts.

Using a sample of 12,296 firm-year observations over 2003-2012, we find that firms with analyst coverage have a higher ERC, controlling for firm size, growth, and risk. This suggests that stock returns impound more information about earnings when firms are followed by analysts. Further, we examine cross-sectional differences in the relation between analyst following and ERC. ERC increases in the quantity and quality of analysts' information which are proxied by the number of analysts and standard deviation of analysts' forecast errors, respectively. This suggests that the beneficial effect of analyst following is pronounced for firms with more and better analysts' information.

While the beneficial effect of analyst following is well documented in U.S. capital market studies (e.g., Wiersema and Zhang 2011; Washburn and Bromiley 2014; Ioannou and Serafeim 2014), the ability of analysts as an information intermediary is often questionable in emerging markets with a few exceptions (e.g., Ding et al. 2014). 
For example, recent news article finds large forecasts errors by Korean analysts, resulting in shocking many investors at the earnings announcement date (Hwang, 2013). Prior literature finds that Korean analysts' earnings forecasts are not superior to time-series model-based (primarily, random walk) forecasts in terms of accuracy after controlling for timing advantage of analysts, questioning analysts' ability to utilize a much broader set of information than that used by the time-series model (Kim, 1998).

Much of literature on analysts in the Korean capital market focuses on the effect of firm characteristic (including information environment) or analyst characteristics on analysts' forecast accuracy (i.e. Ahn et al. 2006; Kim et al. 2010). However, there is a limited evidence of the effect of analyst coverage on the market investors' use of accounting information in the Korean capital market. Accordingly, we contribute to the literature regarding analysts' contributions to informational efficiency in emerging capital market by examining the interplay between analysts and investors' use of accounting information.

The remainder of the paper is organized as follows. Section 2 discuss a related research, develops hypotheses, and outlines the research design. Sample selection and empirical results are presented in Section 3. Finally, Section 4 offers concluding remarks.

\section{Related Literature and Hypotheses Development}

We hypothesize that financial analysts enhance investors' valuations of earnings through two different mechanisms. First, as information intermediaries, analysts provide useful reports about a firm's financial performance to investors. In fact, in a score of analyst reports we read, analysts provide a detailed analysis of earnings such as earnings persistence, the effect of one-time charges, etc. after earnings announcement. ${ }^{1}$ This information interpretation and dissemination role of analysts reduces uncertainty about a firm's earnings and thereby facilitates investors' assessment of earnings in their valuation. Such contribution of analysts as information intermediaries is documented in many studies. For example, Asquith et al. (2005) find that analysts interpret previously released information and such interpreted information is useful to market investors. This information interpretation and dissemination role of analysts reduces uncertainty and processing costs about a firm's earnings, both of which decrease a firm's cost of capital (Diamond and Verrecchia 1991; Baiman and Verrecchia 1996). As a cost of capital decreases, investors apply a lower discount adjustment, resulting in a higher earnings response coefficient. Thus, analyst coverage facilitates investors' assessment of earnings in their valuation.

Second, analyst following increases the quality of earnings. Financial analysts are acknowledged as external monitors in Jensen and Meckling (1976) and Healy and Palepu (2001). Prior research finds that this monitoring role of analysts increases the value of a firm (Chung and Jo 1996). Yu (2008) argues that financial analysts can be effective in detecting and deterring earnings management due to their advanced training in accounting and finance and industry knowledge. Consistent with this, he finds that more analysts lead less earnings management. Similar findings are documented in Ahn (2006) using the Korean data. Thus, earnings of a firm with analyst following are likely to have less opportunistic bias and better reflect a firm's underlying economics. Prior research finds stronger market reactions to earnings with less opportunistic bias and less non-opportunistic error in estimating accrual (Francis et al. 2007; Lang et al. 2006). In summary, we expect earnings with analyst following to have a higher market reaction than those without analyst following as the consequence of analysts' role as information intermediaries and external monitors. We formally state the first hypothes is as follows:

H1: The as sociation between earnings and stock returns is stronger for firms with analyst coverage.

\footnotetext{
${ }^{1}$ For example, Daishin Securities issued a report on Hyundai Motors after its 2012 Q2 results (http://imgstock.naver.com/upload/ research/company/1343346661146.pdf). In this report, an analyst reviewed Hyundai's performance in a great detail, suggest ing the info rmation interpretation and dissemination role of analysts.
} 
However, if analyst's information discovery role such as information pre-emption dominates, the association between earnings and stock returns may decrease with analyst coverage. Analytical research shows that the informativeness of pre-disclosure information is inversely related to investors' reaction to subsequent earnings announcement (Holthausen and Verrecchia, 1988; Demski and Feltham, 1994). Empirically, Chen et al. (2010) find that the amount of information in analyst research issued before earnings announcements is negatively associated with the information content of earnings announcements, consistent with analyst research pre-empting the earnings report. Ayers and Freeman (2003) document a weak association between contemporaneous earnings and annual returns, indicating analyst research pre-empting earnings news in the U.S capital market. Thus, the net effect of the information discovery, interpretation and dissemination, and monitor roles of analysts is an empirical issue in the Korean capital market.

If $\mathrm{H} 1$ is reasonably descriptive, the intensity of the relation between earnings and returns may varies predictably with the quantity and quality of analysts' information. From an informational role perspective, more analysts following a firm results in the production of more reports about earnings and their valuation implication. An increase in information about a firm's earnings decreases uncertainty about their persistence or future cash realization, resulting investors' increase in their weight on earnings information. Also, the effect of analyst following on investors' assessment of earnings is likely to be pronounced (or attenuated) by good (poor) quality information about firms' earnings analysts generate. Following Roulstone (2003) and Cheng and Subramanyam (2008), we measure the quantity and quality of analysts' information by the number of analysts and forecast dispersion. From a monitoring perspective, the effect of analysts as external monitors increases in the number of analysts (Yu 2007), resulting in less managed earnings. This leads to a higher investors' valuation of earnings. By linking investor's assessment of earnings to the number of analysts and the dispersion, we provide more direct evidence on their role in the Korean capital markets. We formally state the second hypotheses as follows:

H2a: The as sociation between earnings and stock returns is increasing in the number of analysts following a firm.

H2b: The association between earnings and stock returns is decreasing in the dispersion of analysts' forecasts .

To empirically examine the role of analysts in investors' assessment of earnings, we test whether stock returns differentially reflect the earnings information when a company is followed by analysts. Specifically, we estimate the following equations:

$$
\begin{aligned}
& R E T_{i, t}=\alpha_{0}+\alpha_{1} S_{Z I Z E_{i, t}}+\alpha_{2} L E V E R A G E_{i, t}+\alpha_{3} G R O W T H_{i, t}+\alpha_{4} \text { FOREIGN }_{i, j}+\alpha_{5} \text { BIG_CO }_{i, j}+ \\
& \alpha_{6} \text { YEAR_DUM }_{i . t}+\alpha_{7} \text { INDUSTRY }_{i . t}+\alpha_{8} \text { ANALYST }_{i . t}+\alpha_{9} \Delta N I_{i . t}+\beta_{1} \Delta N I_{i . t} * L E V E R A G E_{i . t}+\beta_{2} \Delta N I_{i . t} * \\
& G_{R O W T H} H_{i, t}+\beta_{3} \Delta N I_{i, t} * F_{R O R E I G N}+\beta_{4} \Delta N I_{i, t} * B I G_{-} C O_{i, t}+\beta_{5} \Delta N I_{i, t} * A N A L Y S T_{i, t}+\varepsilon_{i, t} \\
& R E T_{i, t}=\alpha_{0}+\alpha_{1} \operatorname{SIZE}_{i, t}+\alpha_{2} L E V E R A G E_{i, t}+\alpha_{3} \text { GROWTH }_{i, t}+\alpha_{4} \text { FOREIGN }_{i, j}+\alpha_{5} \text { BIG_CO }_{i, j}+ \\
& \alpha_{6} Y E A R \_D U M_{i, t}+\alpha_{7} I N D U S T R Y_{i, t}+\alpha_{8} A N A L Y S T_{-} N U M_{i, t}\left(\text { or ANALYST_RANK } K_{i, j}\right)+\alpha_{9} \Delta N I_{i, t}+\beta_{1} \Delta N I_{i, t} * \\
& \text { LEVERAGE } E_{i . t}+\beta_{7} \Delta N I_{i . t} * G R O W T H_{i . t}+\beta_{3} \Delta N I_{i . t} * G R O W T H_{i . t}+\beta_{4} \Delta N I_{i . t} * F O R E I G N_{i . t}+\beta_{5} \Delta N I_{i . t} * \\
& B I G_{-} C O_{i, t}+\beta_{6} \Delta N I_{i, t} * A N A L Y S T_{i, t}\left(\text { or } A N A L Y S T_{-} R A N K_{i, j}\right)+\varepsilon_{i, t} \\
& R E T_{i, t}=\alpha_{0}+\alpha_{1} S_{Z I Z E_{i, t}}+\alpha_{2} L E V E R A G E_{i, t}+\alpha_{3} \text { GROWTH }_{i, t}+\alpha_{4} \text { FOREIGN }_{i, j}+\alpha_{5} \text { BIG_CO }_{i, j}+ \\
& \alpha_{6} \text { YEAR_DUM }_{i, t}+\alpha_{7} \text { INDUSTRY }_{i, t}+\alpha_{8} \text { FORECAST_STD }{ }_{i, t}\left(\text { or FORECAST_STD_RANK } K_{i, j}\right)+\alpha_{9} \Delta N I_{i, t}+ \\
& \beta_{1} \Delta N I_{i, t} * L E V E R A G E_{i, t}+\beta_{2} \Delta N I_{i, t} * G R O W T H_{i, t}+\beta_{3} \Delta N I_{i, t} * G R O W T H_{i, t}+\beta_{4} \Delta N I_{i, t} * \text { FOREIGN }_{i, t}+ \\
& \beta_{5} \Delta N I_{i, t} * B_{C I} G_{C O_{i, t}}+\beta_{6} \Delta N I_{i, t} * \beta_{1} \text { FRECAST_STD }{ }_{i, t}\left(\text { or FORECAST_STD_RANK } K_{i, j}\right)+\varepsilon_{i, t}
\end{aligned}
$$

where RET is the 12-month compounded monthly return adjusted for expected returns from the market model from April 1 of the fiscal year t to March 31 of the fiscal year $t+1$. $\Delta$ NI is the difference between current NI and prior NI, where NI is net income, deflated by a firm's market values of April 1 at yeart. SIZE is the natural log of total assets, LEVERAGE is the ratio of long-term liabilities to total assets, and GROWTH is the change in sales divided by year $\mathrm{t}-1$ sales. FOREIGN is the percentage of a firm's equity held by foreign investors at year t. BIG_CO is a dummy variable that is 1 if SIZE is larger than the median SIZE, 0 otherwise. LEVERAGE, GROWTH, FOREIGN, and BIG_CO interact with $\triangle \mathrm{NI}$ in the regression. These interaction terms are included to control for the effect of other 
confounding factors affecting both RET and analyst following. Due to the high correlation between $\Delta$ NI and the interaction term between SIZE and $\Delta$ NI, we include BIG_CO and BIG_CO* $\Delta$ NI (instead of SIZE* $\Delta$ NI) to control for the effect of firm size on the relation between RET and $\Delta \mathrm{NI}$.

ANALYST_NUM is a number of analysts following a firm during year t. ANALYST_RANK is 0 for firm-years with no analyst following, 1 for firm-years with one analyst, 2 for firm-years with two analysts, 3 for firm-years with 3 or 4 analysts, 4 for firms with analyst greater than 4 and less than or equal to 9, 5 for firms with analysts greater than 9 and less than 16, and 6 for firms with 16 analysts or more. We split the observations into 7 groups to mitigate effects of extreme values of the valuation estimates. Since the number of analyst is a discrete variable whose distribution is well skewed as in Table $1,{ }^{2}$ we made some arbitrary cutoffs so that each group has a meaningful number of observations.

FORECAST_STD is the standard deviation of analysts' earnings forecasts made three months before December 31 of year $t$, divided by the $t$ year-ending stock price. FORECAST_STD_RANK is the quartile of the FORECAST_STD. Subscript $i$ and $t$ represent firm and year, respectively. YEAR_DUM and INDUSTRY_DUM are dummy variables that control for year and industry fixed effects.

H1 predicts that the coefficient of the interaction between $\triangle \mathrm{NI}$ and ANALYST has a positive sign in eq. (1). A positive (negative) and significant coefficient associated with the interaction of $\triangle$ NI and ANALYST_RANK (FORECAST_STD_RANK) in eq. (2) (in eq. (3)) is consistent with H2a (H2b).

\section{EMPIRICAL ANALYSIS}

\section{Sample and Data}

Our initial sample comprises all firm-years on the FnGuide database over the 2003-2012. We delete firm-year observations: (1) from the financial industry; (2) with missing financial statement and returns data required for empirical tests; and (3) with stock returns greater than absolute values of 0.95 and with returns on equity greater than absolute values of 0.95 . This results in a sample of 12,296 firm-year observations. About 33\% of firm-years are followed by analysts. Among firm-years with analyst coverage, $31 \%$ of firm-years are followed by one analyst and more than $50 \%$ of firm-years are followed by less than four analysts as in Table 1 . The median firm with analyst coverage is followed by three analysts.

Table 1. The Number of Analy sts over a Sample Period

\begin{tabular}{c|c|c}
\hline \# of analysts & \# of firm-years & Percent \\
\hline $\mathbf{1}$ & 1,291 & 31.58 \\
\hline $\mathbf{2}$ & 666 & 16.29 \\
\hline $\mathbf{3}$ & 372 & 9.1 \\
\hline $\mathbf{4}$ & 259 & 6.34 \\
\hline $\mathbf{5}$ & 185 & 4.53 \\
\hline $\mathbf{6}$ & 155 & 3.79 \\
\hline $\mathbf{7}$ & 119 & 2.91 \\
\hline $\mathbf{8}$ & 111 & 2.72 \\
\hline $\mathbf{9}$ & 89 & 2.18 \\
\hline $\mathbf{1 1}$ & 87 & 2.13 \\
\hline $\mathbf{1 2}$ & 90 & 2.2 \\
\hline
\end{tabular}

(Table 1 continued on next page)

\footnotetext{
${ }^{2}$ About $65 \%$ of firm-years are not followed by analysts. Among firm-years with analyst following, about $32 \%$ and $16 \%$ are followed by one and two analysts, respectively while less than $20 \%$ are followed by more than 11 analysts.
} 
(Table 1 continued)

\begin{tabular}{|c|c|c|}
\hline \# of analysts & \# of firm-years & Percent \\
\hline $\mathbf{1 3}$ & 71 & 1.74 \\
\hline $\mathbf{1 4}$ & 81 & 1.98 \\
\hline $\mathbf{1 5}$ & 59 & 1.44 \\
\hline $\mathbf{1 6}$ & 70 & 1.71 \\
\hline $\mathbf{1 7}$ & 52 & 1.27 \\
\hline $\mathbf{1 8}$ & 62 & 1.52 \\
\hline $\mathbf{1 9}$ & 46 & 1.13 \\
\hline $\mathbf{2 0}$ & 43 & 1.05 \\
\hline $\mathbf{2 1}$ & 38 & 0.93 \\
\hline $\mathbf{2 2}$ & 34 & 0.83 \\
\hline $\mathbf{2 3}$ & 15 & 0.37 \\
\hline $\mathbf{2 4}$ & 10 & 0.24 \\
\hline $\mathbf{2 5}$ & 10 & 0.24 \\
\hline $\mathbf{2 6}$ & 6 & 0.15 \\
\hline $\mathbf{2 7}$ & 2 & 0.05 \\
\hline $\mathbf{2 8}$ & 1 & 0.02 \\
\hline Total & 1 & 0.02 \\
\hline
\end{tabular}

\section{Descriptive Statistics}

Table 2 reports the summary statistics for the key variables. Over the sample period, mean and median of annual returns, RET, are $-7 \%$ and $-5 \%$, respectively. The average (median) firm size, SIZE, in terms of total assets is 730 (95) billion won while the mean (median) log-transformed leverage, LEVERAGE, relative to total assets is 0.10 and 0.07. During the sample period, an average firm records $5 \%$ sales growth and $7 \%$ of the sample firms, on average, are owned by foreign investors.

Table 3 reports the Pears on correlations among the key variables. RET has a significant and positive correlation with SIZE and GROWTH (log-transformed growth in sales). RET is negatively correlated with LEVERAGE. Changes in Earnings, $\Delta$ NI, are positively correlated with RET as in numerous association studies (i.e. Ball and Brown, 1968). The number of analysts is positively correlated with SIZE and GROWTH consistent with Bhushan (1989) and Lobo et al. (2012). LEVERA GE also has a positive correlation with the number of analyst.

Table 2. Descriptive Data

\begin{tabular}{l|c|c|c|c|c}
\hline \multicolumn{1}{c|}{ Variable } & Mean & S.D & $\mathbf{2 5 \%}$ & Median & $\mathbf{7 5 \%}$ \\
\hline RET & -0.07 & 0.44 & -0.31 & -0.05 & 0.2 \\
\hline SIZE (in millions) & 730000 & 4000000 & 47000 & 95000 & 250000 \\
\hline LEVERAGE & 0.1 & 0.09 & 0.03 & 0.07 & 0.14 \\
\hline GROWTH & 0.05 & 0.43 & -0.07 & 0.06 & 0.18 \\
\hline FOREIGN & 0.07 & 0.12 & 0 & 0.01 & 0.07 \\
\hline$\Delta$ NI & -0.01 & 0.35 & -0.07 & 0 & 0.05 \\
\hline \# of ANALYST & 1.8 & 4.21 & 0 & 0 & 1
\end{tabular}

Notes: RET is the 12-month compounded monthly return adjusted for expected returns from the market model from April 1 of the fiscal yeart to March 31 of the fiscal year $t+1$. $\Delta \mathrm{NI}$ is the difference between current NI and prior NI deflated by a firm's market values of April 1 at y ear $t$, where NI is net income. SIZE is the natural log of total assets (which is log-transformed later in the regression analysis), LEVERAGE is the natural log of (1+long term liabilities/total assets), and GROWTH is the natural log of (1+growth in sales). FOREIGN is the $n$ atura 1 log of $(1+$ percentage of a firm's equity held by foreign investors at year $t)$.\# of ANALYST indicates the number of analysts follo wing a firm. 
Table 3. Pearson Correlations

\begin{tabular}{|c|c|c|c|c|c|c|}
\hline & RET & SIZE & LEVERAGE & GROWTH & FOREIGN & DNI \\
\hline \multirow{2}{*}{ SIZE } & 0.0194 & & & & & \\
\hline & -0.031 & & & & & \\
\hline \multirow{2}{*}{ LEVERAGE } & -0.0615 & 0.1395 & & & & \\
\hline & $(<0.001)$ & $(<0.001)$ & & & & \\
\hline \multirow{2}{*}{ GROWTH } & 0.0955 & 0.0099 & 0.0097 & & & \\
\hline & $(<0.001)$ & -0.27 & -0.2799 & & & \\
\hline \multirow{2}{*}{ FOREIGN } & 0.0333 & 0.2882 & 0.0085 & 0.0189 & & \\
\hline & $(<0.001)$ & $(<0.001)$ & -0.3434 & -0.0359 & & \\
\hline \multirow{2}{*}{$\Delta \mathrm{NI}$} & 0.0977 & 0.0028 & -0.0403 & 0.0923 & 0.0065 & \\
\hline & $(<0.001)$ & -0.756 & $(<0.001)$ & $(<0.001)$ & -0.472 & \\
\hline \multirow{2}{*}{ \# of ANALYST } & 0.0097 & 0.3971 & 0.1092 & 0.0389 & 0.4934 & 0.0102 \\
\hline & -0.281 & $(<0.001)$ & $(<0.001)$ & $(<0.001)$ & $(<0.001)$ & -0.255 \\
\hline
\end{tabular}

Notes: All variables are previously defined. P-values are reported in parentheses.

\section{Results}

Table 4 presents the results of estimating Eq. (1) using a pooled sample over the 2003-2012 period with both a year and industry fixed-effects. We winsorize independent variables at the 1 percent and 99 percent levels to mitigate the effect of extreme values. To facilitate the comparis on with prior literature, we first estimate the returns -earnings association model without analyst variables. The coefficient of $\Delta \mathrm{NI}$ is positive and significant in explaining contemporaneous stock returns, suggesting the value relevance of earnings as in prior literature. The coefficients of SIZE and GROWTH (LEVERAGE) are positive (negative) and significant. The directions of the coefficients are similar to those in Kim et al. (2012).

Turning to the estimation results of Eq. (1), we find a positive and significant coefficient of the interaction between $\triangle \mathrm{NI}$ and ANALYST, which is a dummy variable indicating analyst coverage. When a firm is followed by analysts, the earnings response coefficient dramatically increase from 0.366 to $0.725(=0.366+0.359)$. This is consistent with H1, suggesting that analyst coverage facilitates investors' assessment of earnings. A higher earnings multiple also indicates that interpretation and dissemination role of analyst is likely to dominate in the Korean capital market over information discovery and pre-emption role which are documented in U.S studies (Ayers and Freeman, 2003). The coefficients on the interactions between $\triangle \mathrm{NI}$ and GROWTH, FOREIGN, BIG_CO are not significant. In contrast, we find a statistically significant and negative coefficient on the interaction between $\triangle$ NI and LEVERAGE. This implies that investors place less valuation weight on net income as financial health of a firm decreases, consistent with Barth et al. (1998).

Table 5 reports the results of estimating Eq. (2). The coefficients of the interaction between $\Delta$ NI and ANALYST_NUM and ANALYST_RANK, which ranks firm-years into 7 groups by the number of analysts following a firm, are positive and significant. The estimated coefficient translates into increase in the earnings response coefficient of 0.592 for the 7 th group (a group of firm-years with 16 analysts or more) relative to the first group (a group of firm years with no analyst following). This supports $\mathrm{H} 2 \mathrm{a}$ which states that the association between earnings and stock returns is increasing in the number of analysts following a firm. As in Table 4, the coefficients on other interaction terms except for $\triangle \mathrm{NI} *$ LEVERA GE are not significant.

The test of $\mathrm{H} 2 \mathrm{~b}$ is based on firm-year observations with two or more analysts because the standard errors of analysts' forecasts cannot be defined for observations with zero or one analyst. Table 6 reports the results of estimating Eq. (3). The explanatory power (adjusted R2) dramatically increases to about 32\% from 9\% in the previous results. This high explanatory power sugges ts that a few of accounting numbers explain return variability of large and profitable firms with analyst following. As predicted, the coefficients on both of interaction terms of interest $\left(\triangle N I^{*}\right.$ FORECAST_STD and $\triangle \mathrm{NI}^{*}$ FORECAST_STD_RANK) are negative and significant for the sample of firm-years with two or more analysts. This implies that the quality of analyst coverage affect the market investors' valuation of earnings. In other words, investors decrease in the earnings response coefficient of 0.576 for the $4 \mathrm{th}$ quartile group (lowest quality analysts) relative to the first quartile (highest quality analysts). In addition, the 
coefficient on the interaction between $\triangle \mathrm{NI}$ and BIG_CO is negative and significant, indicating that a larger firms that have a better information environment have a lower ERC. This is consistent with the finding in Collins and Kothari (1989). Overall, these results relating to $\mathrm{H} 2$ suggest that the beneficial effect of analyst following on investors' valuation of earnings arises through the quality and quantity of analysts' information.

Table 4. The Effect of Analy st Following on Investors' Assessment of Earnings

\begin{tabular}{|c|c|c|c|c|}
\hline Dep. Var=RET & \multicolumn{2}{|c|}{ Benchmark Model } & \multirow{2}{*}{$\begin{array}{c}\text { Eq. (1) } \\
\text { Estimate }\end{array}$} & \multirow[b]{2}{*}{ T-Stat } \\
\hline Variables & Estimate & T-S tat & & \\
\hline Year Intercept & Included & & Included & \\
\hline Industry Intercept & Included & & Included & \\
\hline SIZE & 0.025 & $7.19 * * *$ & 0.021 & $4.39 * * *$ \\
\hline LEVERAGE & -0.359 & $-8.71 * * *$ & -0.379 & $-9.10 * * *$ \\
\hline GROWTH & 0.055 & $6.10 * * *$ & 0.051 & $5.47 * * *$ \\
\hline FOREIGN & -0.145 & -0.38 & 0.005 & 0.14 \\
\hline BIG_CO & & & 0.033 & $2.84 * * *$ \\
\hline ANALYST & & & -0.029 & $-3.14 * * *$ \\
\hline$\Delta \mathrm{NI}$ & 0.317 & $17.82 * * *$ & 0.366 & $12.85 * * *$ \\
\hline$\triangle \mathrm{NI} *$ LEVERAGE & & & -0.655 & $-4.05 * * *$ \\
\hline$\Delta \mathrm{NI} * \mathrm{GROWTH}$ & & & 0 & -0.01 \\
\hline$\Delta \mathrm{NI} * \mathrm{FOREIGN}$ & & & 0.143 & 0.68 \\
\hline$\Delta \mathrm{NI} * \mathrm{BIG} \_\mathrm{CO}$ & & & -0.036 & -0.94 \\
\hline$\triangle \mathrm{NI} * \mathrm{ANALYST}$ & & & 0.359 & $6.61 * * *$ \\
\hline No. Obs. & 12,296 & & & 12,296 \\
\hline Adj. R-Square & 0.087 & & & 0.093 \\
\hline
\end{tabular}

Notes: $* * *, * *$, and $*$ represent $1 \%, 5 \%$ and $10 \%$ significance, respectively. The models are estimated using ordin ary least squares (OL S). ANALYST equals one for a firm-year with analyst coverage. All other variables are previously defined. All independent variables are winsorized at the 1 percent and 99 percent levels.

Table 5. The Effect of the Number of Analy sts' Forecasts on Investors' Assessment of Earnings

\begin{tabular}{|c|c|c|c|c|}
\hline Dep. Var=RET & Eq. (2) & & & \\
\hline Variables & Estimate & T-S tat & Estimate & T-S tat \\
\hline Year Intercept & Included & & Included & \\
\hline Industry Intercept & Included & & Included & \\
\hline SIZE & 0.025 & $4.79 * * *$ & 0.027 & $5.13 * * *$ \\
\hline LEVERAGE & -0.378 & $-9.08 * * *$ & -0.381 & $-9.17 * * *$ \\
\hline GROWTH & 0.054 & $5.82 * * *$ & 0.053 & $5.75 * * *$ \\
\hline FOREIGN & 0.026 & 0.67 & 0.029 & 0.74 \\
\hline BIG_CO & 0.026 & $2.22 * *$ & 0.029 & $2.49 * *$ \\
\hline ANALYST_NUM & -0.004 & $-3.43 * * *$ & & \\
\hline ANALYST_RANK & & & -0.013 & $-4.35 * * *$ \\
\hline$\Delta \mathrm{NI}$ & 0.38 & $13.29 * * *$ & 0.38 & $13.34 * * *$ \\
\hline$\Delta \mathrm{NI} * \mathrm{BIG} \_\mathrm{CO}$ & 0.015 & 0.95 & -0.014 & -0.37 \\
\hline$\triangle \mathrm{NI} *$ LEVERAGE & -0.705 & -4.35 & -0.685 & $-4.36 * * *$ \\
\hline$\triangle \mathrm{NI} * \mathrm{GROWTH}$ & 0.005 & 0.15 & 0.001 & 0.04 \\
\hline$\triangle \mathrm{NI} * \mathrm{FOREIGN}$ & 0.192 & 0.21 & 0.108 & 0.51 \\
\hline$\triangle N I * A N A L Y S T$ NUM & 0.022 & $2.81 * * *$ & & \\
\hline UNI*ANALYST_RANK & & & 0.085 & $4.70 * * *$ \\
\hline No. Obs. & 12,296 & & & 12,296 \\
\hline Adj. R-Square & 0.09 & & & 0.092 \\
\hline
\end{tabular}

Notes: $* * *, * *$, and $*$ represent $1 \%, 5 \%$ and $10 \%$ significance, respectively. ANALYST_NUM is a number of analysts following a fir m duri $\mathrm{n} g$ year $t$. ANALYST_RANK is 0 for firm-years with no analyst following, 1 for firm-years with one analyst, 2 for firm-years with two analysts, 3 for firm-years with 3 or 4 analysts, 4 for firms with analyst greater than 4 and less than or equal to 9,5 for firms with analysts greater than 9 and less than 16 , and 6 for firms with 16 analysts or more. 
Table 6. The Effect of the Dispersion of Analy sts' Forecasts on Investors' Assessment of Earnings

\begin{tabular}{|c|c|c|c|c|}
\hline Dep. Var=RET & Eq. (3) & & & \\
\hline Variables: & Estimate & T-Stat & Estimate & T-S tat \\
\hline Year Intercept & Included & & Included & \\
\hline Industry Intercept & Included & & Included & \\
\hline SIZE & 0.009 & 1.21 & 0.017 & $2.21 * *$ \\
\hline LEVERAGE & -0.104 & $-1.42 * * *$ & -0.388 & $-9.34 * * *$ \\
\hline GROWTH & 0.04 & $1.83 *$ & 0.053 & $5.75 * * *$ \\
\hline FOREIGN & 0.062 & 1.17 & 0.025 & 0.64 \\
\hline BIG_CO & 0.059 & $2.63 * * *$ & 0.052 & $2.39 * *$ \\
\hline FORECAST_STD & -2.446 & $-11.06 * * *$ & & \\
\hline FORECAST_STD_RANK & & & -0.069 & $-11.15 * * *$ \\
\hline$\Delta \mathrm{NI}$ & 1.335 & $10.86 * * *$ & 1.793 & 8.58 \\
\hline$\Delta \mathrm{NI} * \mathrm{BIG} \_\mathrm{CO}$ & -0.426 & $-2.89 * * *$ & -0.384 & $-2.56 * * *$ \\
\hline$\triangle \mathrm{NI} * \mathrm{LEVERAGE}$ & -1.5 & $-2.99 * * *$ & -1.965 & $-3.96 * * *$ \\
\hline$\triangle \mathrm{NI} * \mathrm{GROWTH}$ & 0.07 & 0.48 & 0.033 & 0.22 \\
\hline$\Delta \mathrm{NI} *$ FOREIGN & 0.724 & 0.502 & 0.738 & 1.47 \\
\hline$\triangle \mathrm{NI} * \mathrm{FORECAST}$ _STD & -1.883 & $-2.19 * *$ & & \\
\hline $\triangle$ NI*FORECAST_STD_RANK & & & -0.144 & $2.50 * * *$ \\
\hline No. Obs. & 2,651 & & & 2,651 \\
\hline Adj. R-Square & 0.319 & & & 0.319 \\
\hline
\end{tabular}

Notes: $* * *, * *$, and * represent $1 \%, 5 \%$ and $10 \%$ significance, respectively. FORECAST STD is the standard deviation of analy sts' earnin gs forecast s made three months before December 31 of year $t$, divided by the $t$ year-ending stock price.FORECAST_STD_RANK is the quartile of the FORECAST_STD.

\section{Sensitivities and Limitations of Results}

The reported results in this paper are robust to the choice of abnormal returns - raw returns or size-adjusted returns. The variance inflation factors for all variables (except for industry dummies) are less than 3 , suggesting that the estimated coefficients are not significantly influenced by the multicollinearity. However, we cannot rule out the possibility that the statistical significance relating to some of tests may be due to omitted correlated variables (particularly, institutional holdings). Prior literature finds that analyst following and institutional holdings are closely associated (O'Brien and Bhushan, 1990). Institutional investors are presumed be sophisticated and are more likely to utilize earnings information in their investment decision. This makes stock returns impound more information about earnings. Unfortunately, information about domestic institutional holdings is no longer publicly available since 2002 and thus cannot be included as a control. Therefore, we acknowledge a possible alternative explanation while the results based on a sample of firm years only with analyst following (H2a-the effect of analyst information quality on investors'assessment of earnings) are less likely to be influenced by institutional holdings.

\section{CONCLUDING REMARKS}

This study aims for a better understanding of the role of analysts in the Korean capital market. We hypothesize that analyst following increase investors' valuation of earnings because of analysts' roles as both the information intermediaries and the external monitors. Consistent with our hypothesis, we find that analyst coverage is positively correlated with investors' valuation of earnings in the returns-earnings framework. The intensity of this relation varies predictably with the quantity of and quality of analysts' information, which are proxied by the number of analysts and the standard errors of analysts' forecasts, respectively.

While there is a large literature on the effect of analysts following in the Korean capital market, little, if any, empirical work has been conducted so far in the interaction between investors' use of accounting information and the role of analysts. Thus, our evidence on the beneficial effect of analyst following on market investors' assessment of earnings contribute to the literature on the effects of financial analysts on the emerging stock markets and on the determinants of earnings response coefficients. 


\section{ACKNOWLEDGMENT}

This paper was supported under the Supporting Business for University Entrepreneurship Center 2015 supervised by Small and Medium Business Administration (SMBA) and Korea Institute of Startup \& Entrepreneurship Development.

\section{AUTHOR BIOGRAPHY}

Sukyoon Jung is an Assistant professor at School of Business, Hanyang University. He received his Ph.D. in Accounting from the University of Florida. His research areas of interest include financial reporting and disclosure regulation for financial institutions. He is the first author of this research.

Yong-Seok Lee is an Assistant professor at College of Economics and Business Administration, Hannam University. He received his Ph.D. in business administration from the Hanyang University. His research areas include financial accounting and corporate disclosure.

Seong-jin Choi is an Assistant professor at School of Business, Hanyang University. His main research interests include the corporate political strategy and international knowledge spillover in emerging markets. His research has appeared in Organization Science and International Journal of Technology Management. He is the corresponding author of this research. (seongjin@hanyang.ac.kr)

\section{REFERENCES}

Ahn, Y. \& Chang, J. (2006). The Relation between analy st activity and earnings quality and its impact on the firm value. The Korean Academic Association of Business Administration Research Vol.19 No.3: pp.933-959.

Ahn, Y., Yoo, T., Cho, Y., Shin, H., \& Chang, J. (2006). Financial Analyst, Earnings Forecast Accuracy, Earnings Forecast Error, Analy sts-Specific Characteristics. Korean Accounting Review, 31(4), 1-24.

Asquith, P.. Mikhail. M.B., \& Au, A.S. (2005). Information content of equity analy st reports. Journal of Financial Economics, 75(2): 245-282.

Ayers, B.C. \& Freeman, R.N. (2003). Evidence that analy st following and institutional ownership accelerate the pricing of fut ure earnings. Review of Accounting Studies, 8(1): 47-67.

Ball, R., \& Brown, P. (1968). An empirical evaluation of accounting income numbers. Journal of Accounting Research, 6(2): 159-178.

Barth, M.E., Beaver, W.H., \& Landsman, W.R. (2001). The relevance of the value relevance literature for financial accounting standard setting: another view. Journal of Accounting and Economics, 31(1): 77-104.

Basu, S. (1997). The conservatism principle and the asy mmetric timeliness of earnings. Journal of Accounting and Economics, 24(1): 3-37.

Bhushan. R. (1989). Firm characteristics and analv st following. Journal of Accounting and Economics. 11(2): $255-274$.

Cheng, M., \& Subramany am, K.R. (2008). Analyst Following and Credit Ratings. Contemporary Accounting Research, 25(4): 1007-1044.

Chung, K.H., \& Jo, H. (1996). The impact of security analy sts' monitoring and marketing functions on the market value of firms. Journal of Financial and Quantitative Analysis, 31(4): 493-512

Collins, D. W.. \& Kothari. S.P. (1989). An analv sis of intertemporal and cross-sectional determinants of earnings response coefficients. Journal of Accounting and Economics, 11(2): 143-181.

Demski, J.S., \& Feltham, G.A. (1994). Market response to financial reports. Journal of Accounting and Economics, 17(1): 3-40.

Ding, F., Chen, M, \& Wu, Z. (2014). Do Institutional Investors Use Earnings Forecasts from Financial Analy sts? Evidence from China's Stock Market. Emerging Markets Finance and Trade 50(S1): 134-147.

Francis, J., Lafond, R., Olsson, P., \& Schipper, K. (2007). Information Uncertainty and Post-Earnings-AnnouncementDrift. Journal of Business Finance and Accounting, 34(3-4): 403-433.

Holthausen, R.W., \& Verrecchia, R.E. (1988). The effect of sequential information releases on the variance of price changes in an intertemporal multi-asset market. Journal of Accounting Research, 26(1): 82-106.

Hwang, J. (2013). So much error in analvsts' earnings forcasts. Maeil Business Newspaper (August 8) http ://news.mk.co.kr/newsRead.php ?y ear $=2013$ andno $=692370$

Healy, P.M., \& Palepu, K. G. (2001). Information asymmetry, corporate disclosure, and the capital markets: A review of the empirical disclosure literature. Journal of Accounting and Economics, 31(1): 405-440.

Ioannou, I.. \& Serafeim. G. (2014). The impact of corporate social responsibilitv on investment recommendations: Analy sts' perceptions and shifting institutional logics. Strategic Management Journal, 36(7): 1053-1081 
Jensen, M.C., \& Meckling, W. H. (1976). Theory of the firm: Managerial behavior, agency costs and ownership structure. Journal of Financial Economics, 3(4): 305-360

Kim, M., An, H., \& Kim J. (2012). The impact of international diversification on value relevance of earnings. Korean Accounting Review, 37(4):157-193

Kim, J., Paik, J., \& Goh, J. (2010). The Effect of Accrual Quality and Analy sts' Information Environments on Analy sts' Forecast Accuracy. Korean Accounting Review, 35(3): 1-35

Kim, K. (2012). The Market Reaction on Analy st Research and Determinants of the Informativeness. Korean Accounting Review, 37(3): 11-156

Kormendi, R., \& Lipe, R. (1987). Earnings innovations, earnings persistence, and stock returns. Journal of Business, 60(3): 323 345.

Lang, M., Smith Raedy, J., \& Wilson, W. (2006). Earnings management and cross listing: Are reconciled earnings comparable to US earnings? Journal of Accounting and Economics. 42(1): 255-283

Lobo, G. J., Song, M., \& Stanford, M. (2012). Accruals quality and analy st coverage. Journal of Banking and Finance, 36(2): 497-508.

Marhfor, Ahmed, Bouchra M'Zali, \& Guy Charest. (2010). Stock Price Informativeness and Analyst Coverage. Working Paper, University of Quebec at Montreal.

O'Brien. P.C.. \& Bhushan. R. (1990). Analv st following and institutional ownership. Journal of Accounting Research. 28: 55-76.

Roulstone, D. T. (2003). Analy st following and market liquidity*. Contemporary Accounting Research, 20(3): $552-578$.

Teoh, S. H., \& Wong, T. J. (1993). Perceived auditor quality and the earnings response coefficient. Accounting Review, 68(2): 346-366.

Washburn, M., \& Bromiley, P. (2014). Managers and analysts: An examination of mutual influence. Academy of Management Journal. 57(3): 849-868.

Wiersema, M.F., \& Zhang, Y. (2011). CEO dismissal: The role of investment analy sts. Strategic Management Journal, 32(11): 1161-1182.

Yu, F. F. (2008). Analyst coverage and earnings management. Journal of Financial Economics, 88(2): 245-271. 